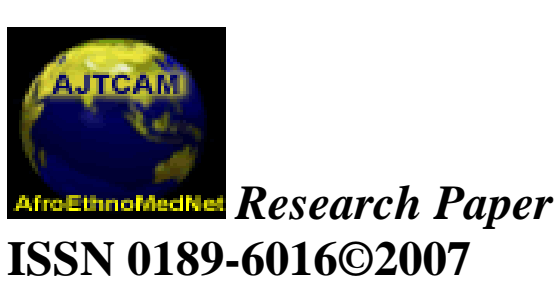

\author{
Afr. J. Traditional, \\ Complementary and \\ Alternative Medicines \\ www.africanethnomedicines.net
}

\title{
BRINE SHRIMP TOXICITY EVALUATION OF SOME TANZANIAN PLANTS USED TRADITIONALLY FOR THE TREATMENT OF FUNGAL INFECTIONS
}

\author{
Mainen J. Moshi*a, Carolien J.P. van den Beukel ${ }^{\mathrm{b}}$, Omar J.M. Hamza ${ }^{\mathrm{c}}$, Zakaria H. Mbwambo ${ }^{\mathrm{a}}$, \\ Ramadhani O.S. Nondo ${ }^{a}$, Pax J.Masimba ${ }^{a}$, Mecky I.N. Matee ${ }^{d}$, Modest C.Kapingu ${ }^{a}$, Frans \\ Mikx ${ }^{\mathrm{f}}$, Paul E. Verweije, and André J.A.M. van der Ven ${ }^{\mathrm{b}}$. \\ ${ }^{a}$ Institute of Traditional Medicine,Muhimbili University College of Health Sciences (MUCHS), \\ Dar es Salaam, Tanzania., ${ }^{\mathrm{b}}$ Department of General Internal Medicine, Radboud University \\ Nijmegen Medical Center, Nijmegen, The Netherlands,. ${ }^{\circ}$ Department of Oral Surgery and \\ Oral Pathology, MUCHS, Dar es Salaam, Tanzania, . ${ }^{\mathrm{d} D e p a r t m e n t ~ o f ~ M e d i c a l ~ M i c r o b i o l o g y ~ a n d ~}$ \\ Immunology, MUCHS, Dar es Salaam, Tanzania, . 'WHO Collaborating Centre, Dentistry, \\ Radboud University Nijmegen Medical Center, Nijmegen, The Netherlands., ${ }^{\mathrm{f}}$ Department of \\ Medical Microbiology, Radboud University Nijmegen Medical Center, Nijmegen, The \\ Netherlands. \\ E-mail: mmoshi@muchs.ac.tz; Tel: 25522 2150096; Fax 255222150465.
}

\begin{abstract}
Plants which are used by traditional healers in Tanzania have been evaluated to obtain preliminary data of their toxicity using the brine shrimps test. The results indicate that 9 out of 44 plant species whose extracts were tested exhibited high toxicity with $\mathrm{LC}_{50}$ values below $20 \mu \mathrm{g} / \mathrm{ml}$. These include Aloe lateritia Engl.

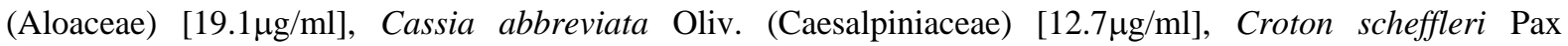

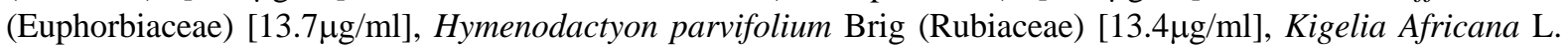
(Bignoniaceae) $[7.2 \mu \mathrm{g} / \mathrm{ml}]$, and Ocimum suave Oliv. (Labiatae) $[16.7 \mu \mathrm{g} / \mathrm{ml}]$. Twelve plants gave $\mathrm{LC}_{50}$ values between 21 and $50 \mu \mathrm{g} / \mathrm{ml}, 11$ plants gave $\mathrm{LC}_{50}$ values between 50 and $100 \mu \mathrm{g} / \mathrm{ml}$, and 18 plants gave $\mathrm{LC}_{50}$ values greater than $100 \mu \mathrm{g} / \mathrm{ml}$.
\end{abstract}

Key words: Brine shrimp test; Toxicity evaluation; Traditional antifungal plants

\section{Introduction}

In sub Saharan Africa, where 70\% of the world cases of HIV/AIDS are found, Candida infections are very common and cause significant morbidity among patients (UNAIDS, 2004). Among problems that hamper effective management of Candida infections in these countries include; limited number of effective antifungal agents, toxicity of the available antifungal agents, resistance of Candida to commonly used antifungals, relapse of candida infections and the high cost of antifungal agents (Debruyne, 1997; Sangeorzan et al., 1994). Reports of resistance to commonly used antifungal agents like fluconazole abound (Ruhnke et al., 1994; Redding et al., 1994), including shifts from Candida albicans to less sensitive species such as Candida glabrata and Candida krusei (Bastert et al., 2001; Powderly, 1992). When relapses occur, the infections tend to be increasingly refractory to treatment.

These problems are of even greater relevance to poor countries, where the choice of antifungal agents is rather limited due to limited resources. In these countries, the most practical option remains to search for cheap alternatives to manage opportunistic infections. The difficulties associated with the management of Candida infections necessitate the discovery of new antifungal agents, in order to widen the spectrum of activity against Candida and combat strains expressing resistance to the available antifungal agents. 
Moshi et al., Afr. J. Trad. CAM (2007) 4 (2): 219 - 225

Plants are widely used in Tanzanian traditional medicine and constitute a potentially useful resource for new and safe drugs for the treatment of opportunistic infections. According to Medicine du Monde, a French nongovernmental organisation, in Kagera region, five out of every six HIV patients receive their medical attention from a traditional healer rather than from a hospital or primary health care facility (AIDS Analysis Africa, 1996). Likewise, a survey conducted in Dar es Salaam showed that $21 \%$ of the people who seek care from public facilities had first consulted a traditional healer (Kilima et al., 1993).

The purpose of the present study was to evaluate the toxicities and/or potential for other biological activities of extracts of the plants that are used by traditional healers in Tanzania for management of fungal infections.

\section{Materials and Methods Plant collection and identification}

Plants reported to be used for the treatment of oral candidiasis and skin fungal infections by the interviewed traditional healers (Table 1) were collected in four regions of Tanzania from February-March 2004. The plants were identified by Mr. Selemani, an experienced botany technician, and voucher specimens are kept at the Herbarium of the Department of Botany, University of Dar es Salaam.

\section{Extraction of plant materials}

All plant samples were air-dried and ground. Approximately 400 grams of the plant materials were macerated with $80 \%$ methanol at room temperature and after $24 \mathrm{~h}$ filtered through Whatman number 1 filter paper. The procedure was repeated three times to ensure exhaustive extraction of the plant material. The extracts were pooled together, concentrated, and the solvent removed by evaporation under reduced pressure in a rotar vapor, at $40^{\circ} \mathrm{C}$. The extracts were further dried by freeze-drying and kept in a freezer, at $-20^{\circ} \mathrm{C}$, until the time of use.

\section{The Brine shrimp lethality test}

The brine shrimp lethality test (BST) was used to predict the presence, in the extracts, of cytotoxic activity (Meyer et al., 1982). Solutions of the extracts were made in DMSO, at varying concentrations, and 30 $\mu \mathrm{l}$ of each incubated in duplicate vials with the brine shrimp larvae in a total volume of $5 \mathrm{ml}$. Ten brine shrimp larvae were placed in each of the duplicate vials. Brine shrimp larvae were placed in a mixture of DMSO (30 $\mu$ l) and seawater to serve as a negative control. Cyclophosphamide, an anticancer drug, was used as a positive control. After $24 \mathrm{~h}$ the nauplii were examined against a lighted background, with a magnifying glass and the average number of survived larvae was determined. The mean percentage mortality was plotted against the logarithm of concentrations and the concentration killing fifty percent of the larvae $\left(\mathrm{LC}_{50}\right)$ was determined from the graph.

\section{Data analysis}

The mean results of brine shrimp mortality against the logarithms of concentrations were plotted using the Fig P computer program (Biosoft Inc, USA), which also gives the regression equations. The regression equations were used to calculate $\mathrm{LC}_{16}, \mathrm{LC}_{50}$ and $\mathrm{LC}_{84}$ values. Confidence intervals (95\% CI) were calculated according to a previously reported method (Litchfield and Wilcoxon, 1949).

\section{Results \\ Brine shrimp lethality}

Among the 65 plant parts collected and belonging to 56 plant species, 50 (76.9\%) plant parts of 44 plant species were tested for brine shrimp lethality. Nine plants showed high toxicity to the shrimps with $\mathrm{LC}_{50}$ values below 20 $\mu \mathrm{g} / \mathrm{ml}$ (Table 2). These include Aloe lateritia $(19.1 \mu \mathrm{g} / \mathrm{ml})$, Cassia abbreviata $(12.7 \mu \mathrm{g} / \mathrm{ml})$, Croton scheffleri $(13.7 \mu \mathrm{g} / \mathrm{ml})$, Hymenodactyon parvifolium $(13.4 \mu \mathrm{g} / \mathrm{ml})$, Kigelia Africana $(7.2 \mu \mathrm{g} / \mathrm{ml})$, and Ocimum suave $(16.7 \mu \mathrm{g} / \mathrm{ml})$. Twelve plants gave $\mathrm{LC}_{50}$ values between 21 and $50 \mu \mathrm{g} / \mathrm{ml}$, 11 plants gave $\mathrm{LC}_{50}$ values between 50 and $100 \mu \mathrm{g} / \mathrm{ml}$, and 18 plants gave $\mathrm{LC}_{50}$ values greater than $100 \mu \mathrm{g} / \mathrm{ml}$. 
Table 1. Herbal plants reported to be used by traditional healers for treatment of fungal infections in Tanzania.

\section{Species (Voucher Specimen No.) \\ Acacia nilotica (L.) Willd ex Del (OH 58)}

Acacia robusta subsp Usambarensis (Taub) Brenan (OH 38)

Acalypha fruticosa Forsk. (OH 56)

Agauria salicifolia Oliv. (OH 45)

Albizia anthelmintica (A. Rich) Brogn (OH 3)

Aloe lateritia Engl. (OH 10)

Annona senegalensis Purs. (OH 11)

Balanites aegyptiaca (L.) Del (OH 17)

Cassia abbreviata Oliv. (OH 20)

Cassia singuena Del (OH 12)

Chrysophyllum bangweolense RE Fris (OH 15)

Cissus petiolata Hook. F. (OH 48)

Clausena anisata Oliv (OH 6)

Commiphora pteleifolia Engl. (OH 34)

Cordia africana Lam (OH 9)

Coronopus didymus (L) (OH 47)

Croton Scheffleri Pax (OH 24)

Cucumis aculeatus Cogn. (OH 32)

Cyphostemma hildebrandtii (Gilg) Desc. (OH 14)

Diospyros usambarensis F. (OH 26)

Drymaria cordata (L) A.Schult (OH 46)

Elaeodendron buchananii (Loes)(OH 19)

Elaeodendron schlechteranum (Loes) (OH 50)

Erythrina abyssinica Lam (OH 18)

Euphorbia heterophylla L. (OH 31)

Euphorbia tirucali L. (OH 57)

Ficus sur. Benth (OH 51)

Gonatopus boivinii Hook.f. (OH 1)
Family

Mimosaceae

Mimosaceae

Euphorbiaceae

Ericaceae

Mimosaceae

Aloaceae

Annonaceae

Balanitaceae

Caesalpinaceae

Caesalpinaceae

Sapotaceae

Vitaceae

Rutaceae

Bursaraceae

Boraginaceae

Cruciferae

Euphorbiaceae

Cucurbitaceae

Vitaceae

Ebenaceae

Caryophyllaceae

Celastraceae

Celastraceae

Papilionaceae

Euphorbiaceae

Euphorbiaceae

Moraceae

Araceae
Local name

Kloriti

Mkame

Siaiti

Mwomboa

Mfuleta

Mapunisinyamviri

Mnene kanda

Mudughuyu

Mufafati

Muhufia

Mseweye

Mswilaswila

Mjavikali

Twini ndedemu

Mgwengweni

Kissango

Muhalange

Ingángáa

Damanyamwili

Muriorio

Ugurashishi

Muhorachwi

Mkandekande

Mkalalwanhuwa

Loo

Injokii

Mkuyu

Kunzulu
Part used $^{\mathrm{a}}$ Life form Preparation

S Shrub Topical

L Tree Topical

L, R Shrub Topical (L),

L Tree Topical

R Tree Oral

WP Shrub Topical

L, R Shrub Topical (L),

RB Tree Topical

R, SB Tree Oral

R Shrub Topical / Oral

RB Tree Topical

$\mathrm{R} \quad$ Climber Topical

L,SB,R Shrub Oral

R Shrub Topical

R Shrub Topical

WP Herb Oral

R Shrub Oral

F Climber Topical

L Herb Topical

R Shrub Topical

WP Herb Topical

SB Tree Oral

SB Tree Oral

$\mathrm{R}$ Tree Topical

WP Herb Oral

L Tree Topical

SB Tree Oral/Topical

T Herb Topical 
Hymenidictyon parvifolium Brig $(\mathrm{OH} 2)$

Hypericum roeperanum Schimp. ex A. Rich (OH 44)

Indigofera rhynchocarpa Bak. Var (OH 16)

Jatropha multifida L. (OH 53)

Khaya anthotheca (Welw.) C.Dc (OH 52)

Kigelia africana L. (OH 49)

Lannea stuhlmanii Engl. (OH 7)

Lobelia giberroa Neumeleg $(\mathrm{OH} 35)$

Ocimum basilicum L. (OH 29)

Ocimum suave Oliv. (OH 13)

Plumbago zeylanica L. (OH 36)

Pteridium aquilinum (L.) Kuhn (OH 41)

Rapanea melanophloeus (L.) Mez (OH 5)

Rhoicissus tridentata (Lf) Wild \& Drumm

(OH 27)

Salvadora persica L (OH 30)

Sclerocarya birrea. (A.Rich.) Hochst. subsp. caffra (Sond.) (OH 8)

Securidaca longipedunculata Fres (OH 28)

Senecio deltoidea Less (OH 33)

Solanum incanum L (OH 23)

Spirostachys africana Sonder (OH 54)

Sterculia africana (Lour) Fiori (OH 39)

Strophanthus eminii Asch \& Pax (OH 25)

Strychnos potatorum Gilg. (OH 21)

Tagetes minuta $\mathrm{L} .(\mathrm{OH} 43)$

Turraea holstii Gurk (OH 37)

Zanthoxylum chalybeum L. (OH 22)

Zehneria scabra (L.f) Sond (OH 42)

Ziziphus pubercens Oliv. (OH 55)

Key: ${ }^{\text {a }}$, Fruit; L, Leaves; R, Roots; RB, Root bark; S, Stem; SB, Stem bark; T, T

$\begin{array}{lllll}\text { Rubiaceae } & \text { Pekawake } & \mathrm{R} & \text { Shrub } & \text { Topical } \\ \text { Gutteferae } & \text { Mwambaziwa } & \mathrm{L} & \text { Shrub } & \text { Topical } \\ \text { Papilionaceae } & \text { Igangula } & \mathrm{R} & \text { Shrub } & \text { Topical } \\ \text { Euphorbiaceae } & \text { Maugwamwipoli } & \mathrm{L}, \mathrm{S}, \mathrm{R} & \text { Shrub } & \text { Topical } \\ \text { Meliaceae } & \text { Mgolaminzi } & \mathrm{SB} & \text { Tree } & \text { Topical } \\ \text { Bignoniaceae } & \text { Mungungu } & \mathrm{RB}, \mathrm{F} & \text { Tree } & \text { Oral } \\ \text { Anacardiaceae } & \text { Muhungilo } & \mathrm{L} & \text { Tree } & \text { Topical } \\ \text { Campanulaceae } & \text { Gongoa } & \mathrm{L} & \text { Herb } & \text { Topical } \\ \text { Labiatae } & \text { Irumbasi } & \mathrm{WP} & \text { Herb } & \text { Oral } \\ \text { Labiatae } & \text { Suameno } & \mathrm{L} & \text { Herb } & \text { Topical } \\ \text { Plumbaginaceae } & \text { Chambula } & \mathrm{R} & \text { Herb } & \text { Oral } \\ \text { Densitraediaceae } & \text { Shilu } & \mathrm{L} & \text { Herb } & \text { Topical } \\ \text { Myrsinaceae } & \text { Mpaja } & \mathrm{L}, \mathrm{SB} & \text { Tree } & \text { Oral } \\ \text { Vitaceae } & \text { Iforiyo } & \mathrm{T} & \text { Climber } & \text { Oral } \\ \text { Salvadoraceae } & \text { Mukunkuni } & \mathrm{R} & \text { Tree } & \text { Topical } \\ \text { Anacardiaceae } & \text { Muongozi } & \mathrm{L}, \mathrm{R} & \text { Tree } & \text { Topical } \\ \text { Polygonaceae } & \text { Musatu } & \mathrm{R} & \text { Shrub } & \text { Oral } \\ \text { Cucurbitaceae } & \text { Ulenge } & \mathrm{WP} & \text { Climber } & \text { Oral } \\ \text { Solanaceae } & \text { Mtula ndulele } & \mathrm{WP} & \text { Herb } & \text { Oral } \\ \text { Euphorbiaceae } & \text { Ormotanga } & \mathrm{S} & \text { Tree } & \text { Topical } \\ \text { Sterculiaceae } & \text { Muhoza } & \mathrm{L} & \text { Tree } & \text { Oral } \\ \text { Apocynaceae } & \text { Muhunguti } & \mathrm{RB} & \text { Shrub } & \text { Oral } \\ \text { Loganiaceae } & \text { Mumpande } & \mathrm{L} & \text { Tree } & \text { Oral } \\ \text { Compositae } & \text { Mbangi } & \mathrm{L} & \text { Climber } & \text { Topical } \\ \text { Meliaceae } & \text { Muhenga } & \mathrm{L} & \text { Shrub } & \text { Oral } \\ \text { Rutaceae } & \text { Mulungu } & \mathrm{RB} & \text { Tree } & \text { Topical/Oral } \\ \text { Cucurbitaceae } & \text { Foiza } & \mathrm{WP} & \text { Climber } & \text { Topical } \\ \text { Rhamnaceae } & \text { Indigrishi } & \mathrm{L} & \text { Shrub } & \text { Topical } \\ \text { Stem bark: T, Tubor: } \text { WP whole plant }{ }^{\mathrm{b} *} \text { No other uses report. } & \\ & & & & \\ & & & \end{array}$


Moshi et al., Afr. J. Trad. CAM (2007) 4 (2): 219 - 225

Table 2: The brine shrimp lethality results represented as $\mathrm{LC}_{50}$ in $\mu \mathrm{g} / \mathrm{ml}$ and $95 \%$ confidence intervals (CI).

\author{
Binomial name \\ Acacia robusta \\ Acalypha fruticosa
}

Agauria salicifolia

Albizia anthelmintica

Aloe lateritia

Balanites aegyptica

Cassia abbreviata

Commiphora pteleifolia

Cordia africana

Croton scheffleri

Chrysophylum banguelense

Cyphosterma hilderbrandtii

Drymaria cordata

Elaeodendron schlechteranum

Elaedendron stuhlmannii

Erythrina abbysinica

Euphorbia heterophylla

Euphobia tirucali

Ficus sur

Hymenodictyon parvifolium

Hypericum roeperanum

Indigofera rhynchocarpa

Jatropha multifida

\section{Khaya anthotheca}

Kigelia africana

\section{Lannea stuhlmannii \\ Lobelia giberroa \\ Ocimum basilicum \\ Ocimum suave \\ Plumbago zeylanica \\ Rapanea melanophloeus}

Rhoicissus tridentate

Salvadore persica

Securidaca longipedunculata

Solanum incanum

Spirostachys africana

\section{Sterculia africana}

Strophanthus eminii

Strychnos pototorum

Tegetes minuta

Turraea holstii

Zanthoxylum chalybeum

Zehneria scabra

Ziziphus pubescens

Cyclophosphamide

\section{Part tested \\ Stem \\ Roots}

Leaves

Leaves

Roots

Whole plant

Root bark

Roots

Roots

Roots

Roots

Root bark

Leaves

Whole plant

Stem bark

Stem bark

Root

Whole plant

Leaves

Stem bark

Roots

Leaves

Roots

Leaves

Stem

Roots

Stem bark

Fruit

Roots

Leaves

Leaves

Whole plant

Leaves

Roots

Stem bark

Leaves

Stem

Roots

Roots

Whole plant

Leaves

Stem

Leaves

Root bark

Leaves

Leaves

Leaves

Root bark

Whole plant

Leaves

$\begin{array}{lc}\mathbf{L C}_{\mathbf{5 0}} \boldsymbol{\mu g} / \mathbf{m l} & (\mathbf{9 5 \%} \mathbf{C I}) \\ 108.5 & 87.8-134.0 \\ 23.9 & 16.5-34.7 \\ 113.9 & 91.2-142.3\end{array}$

$>240$

24.9

19.1

$>240$

12.7

$>240$

211.4

13.7

96.3

25.7

$>240$

37.5

$>240$

$>240$

80.2

196.2

146.1

13.4

46.6

28.3

21.7

58.3

26.1

38.7

$>240$

7.2

25.3

$>240$

85.3

16.7

$>240$

152.4

12.1

$>240$

$>240$

77.1

90.2

16.4

45.2

94.5

38.9

87.6

19.9

96.3

68.9

138.1

68.2

16.3

$$
\begin{gathered}
14.1-44.0 \\
13.2-27.8 \\
- \\
8.1-19.8 \\
- \\
117.6-380.1 \\
21.5-8.7 \\
65.5-141.6 \\
16.9-39.0 \\
- \\
28.1-50.1
\end{gathered}
$$

57.3-112.5

72.7- 529.7

116.1-183.9

8.3-21.5

34.2-63.6

20.5-39.0

16.4-28.7

41.3-82.4

17.3-39. 2

28.6-52.2

3.9-13.8

16.6-38.8

68.2-106.6

11.6-24.1

84.6-274.5

8.6-17.2

45.3-131.1

75.7-107.4

9.4-28.8

24.2-84.5

57.9-154.9

27.4-55.2

39.5-194.2

14.5-27.3

42.5-218.5

36.9-128.6

93.7-203.4

10.6-25.2
50.5-92.1 
Moshi et al., Afr. J. Trad. CAM (2007) 4 (2): 219 - 225

\section{Discussion}

Previous investigations of our group on the in vitro antifungal activity of the plants support the therapeutic claims of the traditional healers (Hamza et al., in Press). Identification of herbal medicines for the treatment of fungal infections in HIV/AIDS patients could be pivotal in supporting the needs of these patients in terms of easy availability, affordability, and possibly to cope with the problem of recurrent Candida infections and emergence of resistance.

Apart from efficacy, safety of herbal medicines is of paramount importance as there is not much that is known about many plants that are used in traditional medicine. We have used the brine shrimp lethality test as a preliminary tool to evaluate the toxicity of the identified plants. Unfortunately not all the plants collected were tested. However, among those tested 9 were quite toxic to the shrimps. Since the test is also used to identify potential anticancer substances, the results may mean that these plants are either outright toxic or may have potential anticancer activity. Two of the plants Euphorbia heterophylla L. (Rocha e Silva, 1943) and Jatropha multifida are reported to be toxic (Levin et al., 2000), thus supporting what was reported by the healers. The extracts of the roots and leaves of Jatropha multifida also exhibited relatively high toxicity on the shrimps, while for Euphorbia heterophylla the toxicity was low $\left(\mathrm{LC}_{50} 80.2 \mu \mathrm{g} / \mathrm{ml}\right)$. Toxicity results from animals will be crucial as a way to definitively judge the safety of these plants, as and when they are found to have enough potential for development. The present results only suggest possibility of other hitherto unreported biological activities, of toxic nature or even anticancer activity. Among the plants tested were seven plants that in earlier investigations of our group showed to have potent antifungal activity (Hamza et al., in Press). The toxic effect of these plants are shown in Table 2. All these plants need to be further investigated for their potential as a source of antifungal compounds.

The results of this toxicity study showed the relative toxicities of the plants. More work is needed in order to determine their usefulness as potential antifungal and anticancer agents.

\section{Acknowledgements}

We are grateful to Mr. Selemani of Botany Department, UDSM, for helping with collection and identification of the plants used in this study. We are grateful to the NAPRALERT Data base of the University of Illinois, at Chicago, for allowing us access to literature.

\section{References}

1. AIDS Analysis Africa, February 1996, pp 12-13.

2. Bastert J, Schaller M, Korting HC, Evans EG (2001). Current and future approaches to antimycotic treatment in the era of resistant fungi and immunocompromised hosts. Intl J Antimicr Agents 17: 8191.

3. Debruyne D (1997). Clinical pharmacokinetics of fluconazole in superficial and systemic mycoses. Clin Pharmacok 33:52-77.

4. Hamza OJM, van den Beukel CJP, Mecky I.N. Matee MIN, Moshi MJ, Mikx F, Haji O. Selemani HO, Mbwambo ZH, Van der Ven AJAM, Verweij PE (2006). Antifungal activity of some Tanzanian plants used traditionally for the treatment of fungal infections. J Ethnopharmacol. May 22; [Epub ahead of print] PMID: 16829001

5. Kilima PM, Ostermayer I, Shija M, Wolff M.M, Evans PJ (1993). Drug utilization, prescribing habits and patients in City Council Health Facilities, Dar es Salaam, Tanzania. DUHP, Swiss Tropical Institute, Basel, p. 19.

6. Levin Y, Sherer Y, Bibi H, Schlesinger M, Hay E (2000). Rare Jatropha multifida intoxication in two children. J Emerg Med 19:173-175.

7. Litchfield Jr JR, Wilcoxon F (1949). A simplified method of evaluating dose-effect experiments. J Pharmacol Exper Therap 96: 99-13.

8. Meyer BN, Ferrigini RN, Jacobsen LB, Nicholas DE, Mc Laughlin JL (1982). Brine shrimp: a convenient general bioassay for active plant constituents. Planta Med 45:31-35.

9. Powerly WG (1992). Mucosal candidiasis caused by non-albicans species of Candida in HIV-positive patients. AIDS 6:604-605. 
Moshi et al., Afr. J. Trad. CAM (2007) 4 (2): 219 - 225

10. Redding S, Smith J, Farinacci G., Rinaldi M, Fothergill A, Rhine-Chalberg J, Pfaller M (1994). Resistance of Candida albicans to fluconazole during treatment of oropharyngeal candidiasis in a patient with AIDS: documentation by in vitro susceptibility testing and DNA subtype analysis. Clin Infect Dis 18:240-242.

11. Rocha e Silva M (1943). Studies on poisonous plants in the state of Sao Paulo: toxicological expts. on 27 plants which have been suspected of toxicity. Arq Instit Biol (Sao Paulo) 14:15.

12. Ruhnke M, Eigler A, Tennagen I, Geiseler B, Engelmann E, Trautmann M (1994). Emergence of fluconazole-resistant strains of Candida albicans in patients with reccurent oro-pharyngeal candidosis and human immunodefficiency virus infection. J Clin Microbiol 32:2092-2098.

13. Sangeorzan JA, Bradley SF, He X, Zarins LT, Ridenour GL, Tiballi RN, Kauffman CA (1994). Epidemiology of oral candidiasis in HIV infected patients: Colonization, infection, treatment, and emergence of fluconazole resistance. Am J Med 97:339-346.

14. UNAIDS (2004). Report on the global AIDS epidemic. 2004 